\title{
Analisis Persepsi Jamaah Umrah Dalam Penerapan Prinsip Syariat Islam Pada Pelayanan Di PT. Cahaya Azami Wisata Jakarta
}

\author{
Oleh: \\ Shofia Tidjani \\ Patmi Pawianti
}

\begin{abstract}
Abstrak: Tujuan dari penelitian ini adalah untuk mengetahui bagaimana persepsi jamaah umrah dalam penerapan syariat Islam pada pelayanan di PT. Cahaya Azami Wisata Jakarta. Metode penelitian yang digunakan adalah deskriptif kuantitatif dengan sumber data berupa data primer dan data sekunder. Adapun data primer diperoleh dari pengisian kuesioner oleh jamaah umrah PT. Cahaya Azami Wisata Jakarta. Sedangkan data sekunder diperoleh dari buku-buku, penelitian dan skripsi sebelumnya. Teknik pengumpulan data yang digunakan adalah kuesioner dan dokumen dari PT. Cahaya Azami Wisata. Penelitian ini mengambil sampel 28 responden yang merupakan jamaah umrah PT. Cahaya Azami Wisata Jakarta. Hasil penelitian ini menunjukkan bahwa prinsip syariah Gharar memiliki tingkat persepsi yang paling tinggi dibandingkan dengan prinsip syariah lainnya, yaitu : maisir, risywah, amanah, kerja sama dan mashlahah. Ini menunjukkan bahwa jamaah umrah sangat membutuhkan informasi pelayanan dan fasilitas yang sangat jelas dari biro perjalanan haji dan umrah.

Kata kunci: Analisis, Persepsi, Jamaah Umrah, Prinsip Syariat Islam, Pelayanan
\end{abstract}

\section{Pendahuluan}

Syariat Islam mengajarkan setiap kemuliaan serta melarang setiap hal yang mendatangkan kehinaan kepada umatnya. Syariat ini berlaku dalam berbagai aspek kehidupan manusia. Mulai dari urusan yang paling kecil hingga yang paling besar, yaitu yang berkaitan dengan harga diri dan tujuan hidup manusia. (Muhammad Arifin Badri:2012:11).

Banyak perintah syariat Islam yang hanya bisa dilaksanakan jika ada uang. Kalau diperhatikan lima rukun Islam, empat rukun tidak dapat terlaksana secara sempurna kecuali dengan uang. Syahadat memang tidak membutuhkan dana, begitu juga dengan shalat. Akan tetapi pendirian masjid atau mushala sebagai konsekwensi yang tak terpisahkan dari shalat serta pembayaran zakat fitrah yang merupakan bagian tak terpisah dari puasa Ramadhan, membutuhkan dana. (Hepi Andi Bastoni:2013:26). 
Begitu juga dengan ibadah haji. Pemerintah dan komisi VIII DPR RI telah menyepakati besaran Biaya Penyelenggaraan Ibadah Haji (BPIH) tahun 2014, rata-rata sebesar Rp 33.799.500,- (Rp 33,8 juta) per orang atau setara 3.219 dolar AS.

Jumlah jamaah haji dan umrah semakin lama semakin meningkat setiap tahunnya di setiap negara-negara Islam, tidak terkecuali di Indonesia. Tahun 2012, Kementerian Agama melarang perusahaan biro perjalanan haji dan umrah untuk memberangkatkan jamaah haji dengan visa non kuota. Kasus menghebohkan terkait masalah ini yaitu pemalsuan data di Jawa Timur. Sejumlah data calon jamaah yang masuk di Tahun 2012 dipalsukan. Pemalsuan ini dilakukan untuk mendapatkan keuntungan yang lebih besar. Porsi jamaah yang seharusnya berangkat pada tahun 2012 diberikan kepada sejumlah jamaah yang seharusnya berangkat tahun 2018. Kecurangan ini melibatkan berbagai pihak, seperti oknum pihak biro perjalanan, oknum pihak Kementerian Agama. (Faisal dan Yatman:2014:25).

Melansir situs Kementerian Agama, kuota haji Indonesia awalnya 211 ribu jamaah, terdiri dari 194 ribu haji reguler dan 17 ribu haji khusus. Pemerintah Arab Saudi meminta Indonesia untuk mengurangi 20 persen atau 42.200 dari total kuota haji tahun 2013. (nasional.tempo:2013).

Banyak jamaah yang lebih dari satu kali melaksanakan ibadah umrah dalam satu tahun. Bagi sebagian orang Indonesia, umrah adalah pilihan ibadah sambil menunggu waktu keberangkatan haji tiba. Hal ini disebabkan masa tunggu haji di Indonesia sangat panjang, berkisar 7 sampai dengan 25 tahun. Begitu pula sebaliknya, orang yang sudah pernah berhaji pun memilih umrah untuk mengobati kerinduan kepada tanah suci. (Abu Hamzah:2015:50).

Kantor Urusan Haji di Jeddah mencatat melalui statistiknya di laman www.kantorurusanhaji.com bahwa jumlah kedatangan dan kepulangan jamaah ibadah umrah Indonesia dari Bulan Januari sampai dengan Bulan April 2015 berjumlah 18.798 orang. (www.kemenag.co.id).

Antusiasme jamaah untuk segera beribadah umrah juga dikarenakan tergiur penawaran biaya paket umrah yang murah. Mereka hanya berpikir yang penting bisa berangkat umrah, tanpa memikirkan apakah segala fasilitas sarana dan prasarana pendukung ibadah akan memberikan kemudahan dan kelancaran beribadah. Padahal kemudahan, kelancaran, kenyamanan fasilitas yang disiapkan oleh biro perjalanan haji dan umrah dapat mendukung kualitas beribadah yang mabrur.

Direktur Jenderal Penyelenggaraan Haji dan Umrah Kementerian Agama Anggito Abimanyu menyatakan salah satu modus utama penipuan 
perjalanan umrah masuk lewat pintu pengajian ibu-ibu. Calon jamaah ditawarkan hotel bintang tiga, dekat Masjidil Haram, dekat Masjid Nabawi. (nasional.tempo:2014).

Laman resmi kantor urusan haji, Rabu (11/02) merilis sekitar 70-an jamaah umrah asal Palembang yang diberangkatkan Biro Perjalanan Wisata (BPW) PT. Rumi (Rumah Manasik Indonesia) telah ditelantarkan. Mereka tidak dapat dipulangkan ke tanah air karena tidak memiliki tiket kembali ke tanah air. (www.kemenag.co.id).

Selain itu, calon jamaah juga mengalami banyak masalah lainnya, seperti gagal berangkat, terlantar di bandara, fasilitas yang dijanjikan tidak sesuai dengan kenyataan bahkan uang jamaah pun turut dibawa lari oleh pemilik biro perjalanan tersebut. (Dirangkum dari SoloPos.com Maret tahun 2014). Bahkan menurut salah seorang pemilik biro perjalanan haji dan umrah, salah satu hal yang meragukan dari sebuah biro perjalanan palsu adalah janji berangkat sesuai jadwal namun belum ada kepastian menyangkut seat (kursi) di pesawat. Sehingga hal ini mengakibatkan walaupun ada jadwal keberangkatan, namun kenyataannya tidak sesuai dengan jadwal yang telah dijanjikan sebelumnya. (denahajiumroh:2015).

\section{Prinsip Syariat Islam Dalam Muamalat}

Abdul Karim Zaidan mendefinisikan bahwa, syariat adalah hukum-hukum yang ditetapkan oleh Allah SWT untuk hamba-Nya, baik melalui al-Qur'an ataupun dengan sunnah Nabi SAW, berupa perkataan, perbuatan dan pengakuan. Menurut Yusuf Qardhawi bahwa, syariat adalah apa saja ketentuan Allah yang dapat dibuktikan melalui dali-dali Al-Qur'an maupun sunnah atau juga melalui dalil-dalil ikutan lainnya seperti ijma, qiyas dan lain sebagainya. Dapat disimpulkan bahwa syariat adalah hukum/peraturan yang datang dari Allah SWT baik melalui Al-Qur'an, sunnah Nabi-Nya maupun ikutan dari keduanya berupa ijma dan qiyas. Jika aturan itu bukan datang dari Allah SWT, ia tidaklah disebut syariat. (Gusfahmi:2007:16-17).

Syariat Islam mempunyai prinsip yang secara keseluruhan merupakan kekhususan (spesifikasi) yang membedakan dengan peraturan-peraturan lainnya. Prinsip-prinsip dasar tersebut ada lima, yaitu : tidak memberatkan, menyedikitkan beban, berangsur-angsur dalam menetapkan hukum, memperhatikan kemaslahatan manusia dalam menetapkan hukum dan keadilan yang merata.

Tujuan Syariat Islam ( Maqhasid Al Syariah)

Menurut ahli ushul fiqih ada lima prinsip dasar yang harus dijaga dan dipelihara oleh manusia, oleh karena itu tujuan syariat Islam adalah : 
untuk memelihara agama (Hifdz Al Din), memelihara jiwa (Hifdz Al Nafs), memelihara akal (Hifdz Al AqI), memelihara harta (Hifdz Al Mal). Prinsip Syariat Islam Dalam Muamalat

Sebagai sistem kehidupan, Islam memberikan warna dalam setiap dimensi kehidupan manusia, tak terkecuali dunia ekonomi. Sistem Islam ini berusaha mendialektikkan nilai-nilai ekonomi dengan nilai akidah ataupun etika. Artinya, kegiatan ekonomi yang dilakukan oleh manusia dibangun dengan dialektika nilai materialisme dan spiritualisme. Kegiatan ekonomi yang dilakukan tidak hanya berbasis nilai materi, akan tetapi terdapat sandaran transendental di dalamnya, sehingga akan bernilai ibadah. (langkahsupian:2012).

Selain itu, konsep dasar Islam dalam kegiatan muamalah (ekonomi) juga sangat konsen terhadap nilai-nilai humanisme. Di antara prinsip-prinsip muamalah adalah sebagai berikut :

a. Prinsip Dasar

1) Prinsip tauhid

Adalah dasar utama dari setiap bentuk bangunan yang ada dalam syariat Islam. Artinya bahwa dalam setiap gerak langkah serta bangunan hukum harus mencerminkan nilainilai ketuhanan. Sehingga dalam tingkatan tertentu dapat dipahami bahwa semua gerak yang ada di alam semesta merupakan gerak dan asma dari Allah SWT.

Dalam bermuamalah yang harus diperhatikan adalah bagaimana seharusnya menciptakan suasana dan kondisi bermuamalah yang tertuntun oleh nilai-nilai ketuhanan. Yaitu seperti keyakinan dalam hati bahwa Allah SWT selalu mengawasi segala gerak langkah kita dan selalu berada bersama kita. Kalau pemahaman semacam ini terbentuk dalam setiap pelaku muamalah (bisnis), maka akan terjadi muamalah yang jujur, amanah dan sesuai tuntunan syariah. (Mardani:2012:8).

2) Prinsip halal

Halal adalah istilah Bahasa Arab dalam agama Islam yang berarti diizinkan atau boleh. Istilah ini dalam kosakata seharihari digunakan untuk merujuk kepada makanan dan minuman yang dikonsumsi menurut dalam Islam. Sedangkan dalam konteks yang lebih luas istilah halalmerujuk kepada segala sesuatu yang diizinkan menurut hukum Islam (aktivitas, tingkah laku, cara berpakaian dll). Di Indonesia, sertifikasi kehalalan produk pangan ditangani oleh Majelis Ulama 
Indonesia-secara spesifik Lembaga Pengkajian Pangan Obatobatan dan Kosmetika Majelis Ulama Indonesia. (firdauzzuel:12/05).

Nadratuzzaman Husen sebagaimana dikutip dalam (Mardani:2012:9) mengemukakan bahwa alasan mencari rezeki (berinvestasi) dengan cara halal, yaitu :

a) Perintah Allah SWT.

b) Mengandung keberkahan.

c) Mengandung manfaat dan mashlahah yang agung bagi manusia.

d) Membawa pengaruh positif bagi perilaku manusia.

e) Melahirkan pribadi yang istiqomah.

f) Membentuk pribadi yang zahid, wira'í, qana'ah, santun dan suci dalam segala tindakan.

g) Melahirkan pribadi yang tasamuh, berani menegakkan keadilan dan membela yang benar.

Sedangkan investasi yang dilakukan secara haram (non halal) hasilnya akan :

a) Memunculkan sosok pendusta, penakut, pemarah dan penyebar kejahatan dalam kehidupan masyarakat.

b) Melahirkan manusia yang tidak bertanggung jawab, pengkhianat, penjudi, koruptor dan pemabuk.

c) Hilangnya keberkahan, ketenangan dan kebahagiaan bagi manusia.

Selain caranya harus halal, barang yang diperjualbelikan juga harus halal. Misalnya dilarang menjual daging bangkai, arak, babi, dan lain-lain. Seseorang yang menjual daging bangkai, yaitu daging binatang yang tidak disembelih secara syar'i maka dia termasuk orang menjual barang haram dan mendapatkan harga pembayaran yang haram.

3) Prinsip ibahah (boleh)

Ibahah adalah firman Allah yang mengandung pilihan bagi mukallaf untuk mengerjakan atau meninggalkannya. Artinya : Katakanlah: "Terangkanlah kepadaku tentang rezeki yang diturunkan Allah kepadamu, lalu kamu jadikan sebagiannya Haram dan (sebagiannya) halal". Katakanlah: "Apakah Allah telah memberikan izin kepadamu (tentang ini) atau kamu mengada-adakan saja terhadap Allah ?"(QS Yunus : 59).

Ayat ini mengindikasikan bahwa Allah memberikan kebebasan dan kelenturan dalam kegiatan muamalah, selain 
itu syariah juga mampu mengakomodir transaksi modern yang berkembang.

4) Prinsip kebebasan bertransaksi

Prinsip kebebasan bertransaksi adalah harus didasari dengan prinsip suka sama suka, juga dengan akad yang sah dan tidak ada pihak yang dizalimi.

5) Prinsip membayar zakat

Mengimplementasikan zakat merupakan kewajiban seorang muslim yang mampu secara ekonomi, sebagai wujud kepedulian sosial.

6) Prinsip keadilan

Keadilan dalam hal ini dapat dipahami sebagai upaya dalam menempatkan hak dan kewajiban antara pihak yang melakukan muamalah. Misalnya keadilan dalam pembagian bagi hasil antara pemilik modal dan pengelola modal. (Mardani:2012:11).

7) Prinsip komitmen terhadap akhlaqul karimah

Seorang pebisnis harus memiliki komitmen kuat untuk mengamalkan akhlak mulia. Seperti berzikir kepada Allah, jujur dan dapat dipercaya, cakap dan komunikatif, sederhana dalam berbagai keadaan, memberi kelonggaran orang yang dalam kesulitan membayar utangnya, menghindari penipuan, kolusi dan manipulasi, atau sejenisnya.

8) Prinsip terhindar dari jual beli dan investasi yang dilarang

Prinsip ini di antaranya adalah :

a). Terhindar dari ihtikaar yaitu penimbunan barang-barang seperti makanan dan kebutuhan sehari-hari. b). Terhindar dari iktinaz yaitu penimbunan seperti uang, emas, perak dan lain sebagainya. c). Terhindar dari tas'ir yaitu penetapan harga standar pasar yang ditetapkan oleh pemerintah atau yang berwenang, untuk disosialisasikan secara paksa kepada masyarakat. d). Terhindar dari upaya melambungkan harga. e). Terhindar dari riba f). Terhindar dari maisir. g). Terhindar dari gharar. h). Terhindar dari syubhat. i). Terhindar dari tadlis. j). Terhindar dari risywah. k). Terhindar dari batil. l). Terhindar dari menjual barang digunakan untuk maksiat. $\mathrm{m}$ ). Terhindar dari jual beli dalam bentuk lainnya. (Mardani:2012:12).

b. Prinsip Umum

1) Al-muawanah / Ta'awun (tolong-menolong)

2) Niat / itikad baik 
3) Kemitraan

4) Adanya kepastian hukum.

Setelah mengenal prinsip-prinsip dalam fiqh muamalat, ada prinsip dasar yang harus dipahami dalam interaksi ekonomi. Ada 5 hal yang perlu diingat sebagai landasan setiap kali seorang muslim akan berinteraksi ekonomi. Kelima hal ini menjadi batasan secara umum bahwa transaksi yang dilakukan sah atau tidak, maupun halal atau tidak lebih dikenal dengan singkatan MAGHRIB, yaitu Maisir, Gharar, Haram, Riba, dan Bathil. (langkahsupian:2012).

Sebagai landasan teori pada penelitian ini, penulis menggunakan prinsip gharar, maisir, risywah, amanah, kerjasama dan mashlahah.

a. Bebas penipuan (gharar)

Gharar berasal dari Bahasa Arab yang berarti resiko, tipuan dan menjatuhkan diri atau harta ke jurang kebinasaan. Menurut istilah para ahli fiqih, gharar berarti jual beli yang tidak jelas kesudahannya. Sebagian ulama mendefinisikannya dengan jual beli yang konsekuensinya antara ada dan tiada. (Tarmizi:2015:205).

Dalil haram ba'i gharar dari Al-Qur'an adalah firman Allah Ta'ala, Artinya : Hai orang-orang yang beriman, sesungguhnya khamar, berjudi, (berkorban untuk) berhala, mengundi nasib dengan panah, adalah termasuk perbuatan syaitan. Maka jauhilah perbuatan-perbuatan itu agar kamu mendapat keberuntungan. Sesungguhnya syaitan itu bermaksud hendak menimbulkan permusuhan dan kebencian di antara kamu lantaran (meminum) khamar dan berjudi itu, dan menghalangi kamu dari mengingat Allah dan shalat, maka berhentilah kamu. (Al-Maidah : 90-91).

Dalil haram ba'i gharar dari hadits :

Diriwayatkan dari Abu Hurairah radhiyallahu 'anhu, yang artinya bahwa : Nabi shallaallahu 'alaihi wa sallam melarang jual beli hashah (jual beli tanah yang sebenarnya ditentukan dengan sejauh lemparan batu) dan juga melarang jual beli gharar. (HR. Muslim). 
Gharar adalah suatu kegiatan bisnis yang tidak jelas kuantitas, kualitas, harga dan waktu terjadinya transaksi. Aktifitas bisnis yang mengandung gharar adalah bisnis yang mengandung resiko tinggi, atau transaksi yang dilakukan dalam bisnis tak pasti. Bisnis semacam ini cukup membahayakan, karena keputusan yang diambil oleh pelaku bisnis lebih bersifat spekulatif (gambling). Kegiatan bisnis yang semacam ini oleh agama Islam dilarang, karena di dalamnya cukup dominan terdapat semangat perjudian.

Jadi kegiatan bisnis syariah harus dilakukan dengan menggunakan transaksi-transaksi yang bebas dari unsur gambling, resiko terlampau tinggi, kegiatan bisnis berpotensi perjudian. Dalam memprediksi resiko kerugian dan hasil yang akan diperoleh, kurang akurat atau tidak jelas. Contoh bisnis yang mengandung unsur ghararyang tinggi adalah bisnis :

1) Sistem ijon.

2) Jual beli atas hasil yang belum pasti.

3) Option.

4) Jual beli ternak yang masih dalam kandungan.

5) Jual beli buah atau tanaman yang belum masa panen.

6) Jual beli yang obyek transaksinya yang tidak ada wujudnya.

7) Dan lain-lain.

Terdapat beberapa sebab bisnis yang dilakukan ini mengandung unsur gharar antara lain :

1) Sifat transaksinya minim informasi atau gelap informasi.

2) Transaksi itu penuh dengan resiko kerugian.

3) Sifat kontraknya sangat kompleks.

4) Berspekulasi dalam kesempatan.

5) Kepastiannya minimal.

Gharar dalam konteks obyek transaksi ini terjadi jika terdukung oleh hal-hal berikut ini :

1) Ketidakjelasan jenis obyek transaksi.

2) Ketidakjelasan dalam macam transaksi.

3) Ketidakjelasan dalam sifat dan karakter obyek transaksi.

4) Ketidakpastian dalam takaran obyek transaksi.

5) Ketidakjelasan dalam materi atau zat obyek transaksi.

6) Ketidakjelasan waktu penyerahan obyek transaksi.

Aktifitas bisnis yang termasuk dalam transaksi ini antara lain adalah :

1) Jual beli atas barang yang tersembunyi di dalam tanah. 
2) Jual beli obral di mana obyeknya disembunyikan dalam karung.

3) Jual beli atas barang yang ditutupi oleh kulitnya.

Syariat Islam melarang jual beli gharar karena dalam jenis jual beli ini terdapat beberapa hal yang merugikan, di antaranya :

1. Jual beli gharar termasuk memakan harta orang lain dengan cara yang batil.

2. Jual beli gharar dapat menimbulkan permusuhan sesama muslim.

Mengumpulkan harta dengan cara untung-untungan dan judi menyebabkan seseorang lupa mendirikan sholat daan zikrullah serta menghancurkan dan menghilangkan keberkahan harta.

Oleh karena itu di dalam bisnis syariah, semua jenis bisnis seperti yang dijelaskan di atas, mengandung bahaya dan banyak merugikan daripada manfaatnya, harus dihindari.

b. Bebas maisir

Maisir adalah suatu kegiatan bisnis yang di dalamnya jelas bersifat untung-untungan atau spekulasi yang tidak rasional, tidak logis, tidak jelas barang yang ditawarkan baik secara kuantitatif maupun secara kualitatif. Aktifitas bisnis yang mengandung maisir adalah kegiatan bisnis yang dilakukan dalam rangka mendapat untung atau mengadu nasib baik dengan melalui kegiatan seperti mengadu ayam, main dadu, menggunakan permainan panah memanah, dan lain-lain. Sebagaimana Firman Allah Artinya : Wahai orang-orang yang beriman! Bahwa sesungguhnya arak, judi, pemujaan berhala dan mengundi nasib dengan batang-batang anak panah, adalah (semuanya) kotor (keji) dari perbuatan syaitan. Oleh karena itu hendaklah kamu menjauhinya supaya kamu beruntung. (AImaidah : 90-91).

Contoh bisnis yang menyerupai sifat maisir ini antara lain :

1) Berbisnis valas.

2) Membuka bandar dengan segala bentuknya.

3) Jual beli barang yang tidak jelas kualitas dan kuantitasnya.

4) Spekulasi bersama partner dalam menentukan skor kemenangan olah raga.

c. Bebas dari risywah

Risywah (sogok atau suap) adalah sesuatu yang diberikan (berupa uang, barang, hadiah ataupun jasa) kepada seorang hakim diinginkannya, baik keinginan tersebut sesuatu yang 
terlarang atau atau siapapun juga, agar hakim, pejabat, aparat dan lainnya berpihak kepada pemberi dengan melakukan apa yang tidak. (Tarmizi:2013:190).

Allah telah melarang tegas perbuatan menyogok dan memakan sogok serta perantaranya. Sebagaimana Firman Allah Artinya : dan janganlah sebagian kamu memakan harta sebahagian yang lain di antara kamu dengan jalan yang bathil dan (janganlah) kamu membawa harta sogok itu kepada hakim, supaya kamu dapat memakan sebahagian daripada harta benda orang lain itu dengan (jalan berbuat) dosa, padahal kamu mengetahui. (Al-Baqarah : 188).

Dan Rasulullah shallallahu 'alihi wa sallam mengutuk dan mendoakan agar orang-orang yang terlibat dalam proses sogok dijauhkan dari rahmat Allah.

Ibnu Umar berkata yang artinya :

Rasulullah shallallahu 'alihi wa sallam melaknat orang yang memberikan sogok dan orang yang menerima sogok. (HR. Abu Daud dan dinyatakan shahih oleh Al-Albani).

\section{d. Sifat maslahah mursalah}

Fiqih muamalah akan senantiasa berusaha mewujudkan kemaslahatan, mereduksi permusuhan dan perselisihan di antara manusia. Allah tidak menurunkan syariah, kecuali dengan tujuan untuk merealisasikan kemaslahatan hidup hamba-Nya, tidak bermaksud memberi beban dan menyempitkan ruang gerak kehidupan manusia. (langkahsupian:2012).

Karakteristik bisnis syariah adalah sifat yang diukur bahwa bisnis yang dilakukan berhubungan erat dengan kepentingan dan persoalan umat dan masyarakat banyak. Hal yang menyangkut berhubungan dengan kepentingan ini cukup penting bagi kehidupan dan kebutuhan positif bagi umat manusia.

Jika yang didirikan sangat berkaitan dengan persoalan umat manusia, seperti dalam rangka memenuhi kebutuhan umat manusia, seperti mendirikan rumah sakit, mendirikan pabrik pupuk tanaman pertanian, pabrik obat-obatan, dan lain-lain. Pengukuran yang dikaitkan dengan kepentingan masyarakat banyak, maka bisnis syariah termasuk dalam kategori wajib dan fardhu kifayah dan sunnah muakkad. Artinya peranan dan fungsi pengaturannya harus didukung dengan perangkat hukum wajib dan sunnah. Pengelolaannya harus lebih mengutamakan kepentingan umum dan demi kesejahteraan umat. 
Kategori bisnis yang memihak kepada permasalahan umat antara lain ditandai dengan maksud dan tujuan yang terukur, yaitu :

1) Untuk meningkatkan kesejahteraan masyarakat.

2) Untuk menjaga keseimbangan dalam kehidupan bersama.

3) Untuk kebaikan dan keselamatan bersama.

4) Untuk kehidupan yang harmonis.

5) Untuk keamanan dalam hidup bersama.

6) Untuk memudahkan dalam kegiatan ibadah umat manusia. (Muslich:2007:45).

Firman Allah dalam prinsip mashlahah Artinya : Dan kami tidak mengutus engkau (Muhammad) melainkan untuk (menjadi) rahmat bagi seluruh alam. (QS. Al-Anbiya : 107).

Sebagaiman Hadits Nabi : Tidak boleh berbuat mudharat dan pula saling memadharatkan. (HR. Ibnu Majah dan Daruquthni).

e. Prinsip amanah

Yaitu prinsip kepercayaan, kejujuran, tanggung jawab. Misalnya dalam hal membuat laporan keuangan, dan lain-lain. Firman Allah dalam prinsip amanah Artinya : Sesungguhnya Allah menyuruh kamu menyampaikan amanah kepada yang berhak menerimanya, dan (menyuruh kamu) apabila menetapkan hukum di antara manusia supaya kamu menetapkan dengan adil. Sesungguhnya Allah memberi pengajaran yang sebaik-baiknya kepadamu. Sesungguhnya Allah adalah Maha Mendengar lagi Maha Melihat.(QS. An-Nisa : 58).

Hadits Nabi tanda-tanda orang munafik ada tiga : jika berbicara ia bohong, jika berjanji ia ingkar dan jika diberi amanah ia berkhianat.

f. Prinsip kerja sama

Prinsip transaksi didasarkan pada kerja sama yang saling menguntungkan dan solidaritas (persaudaraan dan saling membantu).Artinya : Hai orang-orang yang beriman, janganlah kamu melanggar syi'ar-syi'ar Allah dan jangan melanggar kehormatan bulan-bulan haram jangan (mengganggu) binatangbinatang had-ya dan binatang-binatang qalaa-id dan jangan (pula) mengganggu orang-orang yang mengunjungi Baitullah sedang mereka mencari karunia dan keredhaan dari Tuhannya dan apabila kamu telah menyelesaikan ibadah haji, Maka bolehlah berburu. dan janganlah sekali-kali kebencian(mu) kepada sesuatu kaum karena mereka menghalang-halangi kamu dari Masjidil haram, mendorongmu berbuat aniaya (kepada 
mereka). dan tolong-menolonglah kamu dalam (mengerjakan) kebajikan dan takwa, dan jangan tolong-menolong dalam berbuat dosa dan pelanggaran, dan bertakwalah kamu kepada Allah, sesungguhnya Allah amat berat siksa-Nya.

Sebagaimana Hadits Nabi :

Seorang mukmin yang bergaul dengan manusia dan bersabar atas perlakuan mereka adalah lebih baik dan besar pahalanya daripada mukmin yang tidak bergaul dengan manusia dan tidak bersabar atas perilaku manusia. (HR. Imam Ahmad).

\section{Pembahasan}

Berdasarkan nilai mean / rata-rata untuk masing-masing prinsip syariah, diketahui bahwa prinsip syariah maisir(PS2) mempunyai nilai mean tertinggi yaitu 4,7500. Hal ini menunjukkan bahwa jamaah umrah PT.Cahaya Azami Wisata Jakarta sangat merespon baik dengan pemahaman yang dimilkinya. Maisir adalah suatu kegiatan bisnis yang di dalamnya jelas bersifat untung-untungan atau spekulasi yang tidak rasional, tidak logis, tidak jelas barang yang ditawarkan baik secara kuantitatif maupun secara kualitatif.

Aktifitas bisnis yang mengandung maisir adalah kegiatan bisnis yang dilakukan dalam rangka mendapat untung atau mengadu nasib baik dengan melalui kegiatan seperti mengadu ayam, main dadu, menggunakan permainan panah memanah, dan lain-lain. Dengan demikian dapat terlihat jelas bahwa jamaah umrah ketika akan berangkat ibadah umrah, sangat membutuhkan informasi tentang pembuatan visa.

Berdasarkan hasil uji korelasi antar variabel independen ada pada output KMO and Bartlett's Test, tidak terdapat perbedaan yang signifikan antara prinsip syariah gharar (PS1), maisir (PS2), risywah (PS3), amanah (PS4), kerjasama (PS5) dan mashlahah (PS6). Dengan demikian hipotesis ini dapat diterima.

Berdasarkan hasil pengujian dengan menggunakan SPSS pada anti-image matries, diketahui bahwa Gharar (PS1) dengan nilai 0,782 adalah sebagai prinsip syariah yang paling dominan di antara prinsip syariah yang lainnya. Gharar adalah suatu kegiatan bisnis yang tidak jelas kuantitas, kualitas, harga dan waktu terjadinya transaksi.

Aktifitas bisnis yang mengandung gharar adalah bisnis yang mengandung resiko tinggi, atau transaksi yang dilakukan dalam bisnis tak pasti. Bisnis semacam ini cukup membahayakan, karena keputusan yang diambil oleh pelaku bisnis lebih bersifat spekulatif (gambling). 
Kegiatan bisnis yang semacam ini oleh agama Islam dilarang, karena di dalamnya cukup dominan terdapat semangat perjudian.

Dengan demikian dalam penelitian ini dapat diketahui, bahwa prinsip syariah gharar / tidak melakukan penipuan adalah menjadi persepsi jamaah yang paling dominan. Jamaah sangat membutuhkan sekali informasi pelayanan dan fasilitasnya dengan jelas (visa, tiket pesawat pergi pulang, penginapan, makan, muthawif, air zam zam). Dengan kejelasan informasi pelayanan dan fasilitas akan sangat membantu pula dalam kemudahan dan kelancaran beribadah untuk mencapai ibadah umrah yang mabrur.

Demikian hasil hipotesa yang sesuai dengan penelitian Rahmawati (2010) dan Balqis (2008) menyatakan bahwa tidak ada perbedaan yang signifikan antara prinsip syariah gharar (PS1), maisir (PS2), risywah (PS3), amanah (PS4), kerjasama (PS5) dan mashlahah (PS6). Dibandingkan dengan penelitian Nadiatul Khairiyah (2011) terdapat perbedaan dari tujuan penulisan penelitian ini. Penelitian untuk mengetahui apa saja tujuan dalam program umrah dan pelayanan diberikan PT. Mulia Utama Tour Jakarta dan mengetahui kebutuhan jamaah umrah tersebut. Sedangkan tujuan penulis dalam penelitian ini adalah untuk mengetahui tingkat persepsi jamaah umrah dalam penerapan prinsip syariat Islam pada pelayanan di PT. Cahaya Azami Wisata Jakarta.

\section{Kesimpulan}

Dari pembahasan yang telah diuraikan, maka dapat ditarik kesimpulan sebagai berikut :

1. Berdasarkan pengujian dengan SPSS pada pengujian menggunakan analisis faktor, pada pengujian nilai MSA (Measure of Sampling Adequacy) setiap faktor X yaitu gharar (PS1) 0,782, maisir (PS2) 0,738, amanah (PS4) 0,532, dan mashlalah (PS6) 0,510, masingmasing memiliki nilai $>0,5$ sehingga seluruh faktor dapat dianalisis lebih lanjut. Sedangkan risywah (PS3) 0,461 dan kerja sama (PS5) 0,415 masing-masing memiliki nilai $<0,5$ sehingga seluruh faktor tidak dapat dianalisis lebih lanjut. Dengan demikian ada persepsi jamaah dalam PS1, PS2, PS4, dan PS6. Sedangkan pada PS3 dan PS5 tidak ada persepsi jamaah.

2. Dari keenam variabel prinsip syariat Islam tersebut yang digunakan untuk mengukur tingkat persepsi jamaah umrah, bahwa variabel gharar (PS1) memiliki tingkat persepsi paling tinggi di antara variabel yang lainnya yaitu sebesar $0,782(>0,5)$. Hal ini menunjukkan bahwa penerapan prinsip syariat Islam yaitu gharar 
Jurnal Islaminomic, Vol. 6 No. 2, Agustus 2015

(ada kejelasan dan bukan penipuan) sangat diharapkan dalam pelayanan pada PT. Cahaya Azami Wisata Jakarta. 